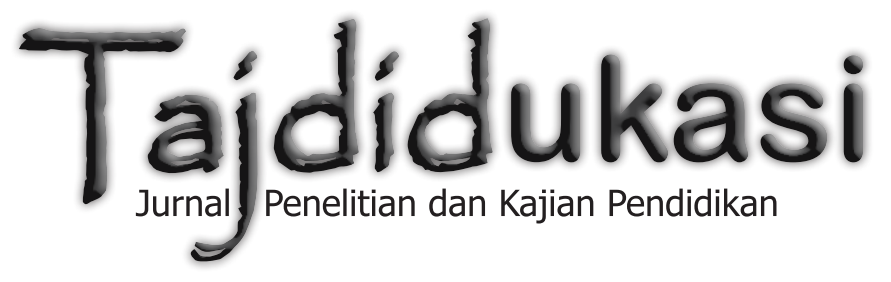




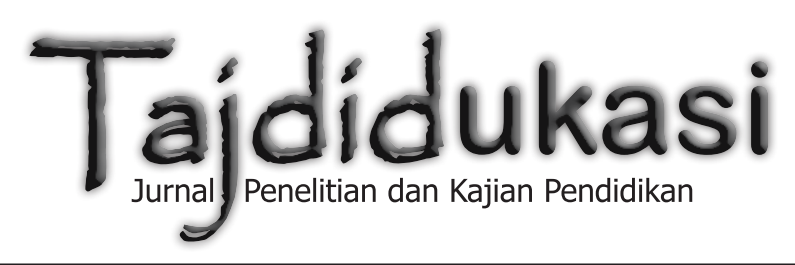

Volume VIII, No. 2, Juli 2018

ISSN: 1979-6943

Tajdidukasi: Jurnal Penelitian dan Kajian Pendidikan merupakan jurnal Penelitian dan Kajian Pendidikan yang berisi Penelitian Tindakan Kelas (PTK) dan Penelitian Tindakan Sekolah (PTS) serta Kajian Pendidikan interdisipliner di Perguruan Tinggi yang diterbitkan Majelis Pendidikan Dasar dan Menengah Pimpinan Wilayah Muhammadiyah Daerah Istimewa Yogyakarta. Artikel hasil PTK dan PTS serta kajian pemikiran pendidikan ditulis oleh para Guru dan Kepala Sekolah serta Dosen dalam mengujicobakan metode dan strategi pembelajaran untuk meningkatkan kualitas pendidikan baik SD/MI, SMP/MTs dan SMA/MA/SMK serta Perguruan Tinggi. Artikel PTK dan PTS fokus pada mata pelajaran di sekolah/madrasah, seperti Ilmu Pengetahuan Alam (IPA), Imu Pengetahuan Sosial (IPS), Matematika, Fisika, Kimia, bahkan teknik, seperti Teknik Mesin, Elektro, Informatika dan lain sebagainya. Sementara itu, artikel Kajian Pendidikan merupakan penelitian interdisipliner dan multidisipliner yang dilakukan Dosen di Perguruan Tinggi terhadap khasanah keIslaman.

Tajdidukasi: Jurnal Penelitian dan Kajian Pendidikan adalah jurnal terbuka yang versi softfile-nya bisa dibaca dan diakses secara gratis, sementara versi print out/ hardcopy dapat diperoleh dengan menghubungi distributor di alamat serial tajdidukasi.ac.id. Sof-file keseluruhan artikel yang diterbitkan dapat diakses melalui Tajdidukasi Open Access Juornal di www.dikdasmenpwmdiy.or.id

Pimpinan Editor
Suyadi, Universitas Ahmad Dahlan (UAD) Yogyakarta, Indonesia

Anggota Editor

Arif Budi Raharjo, Universitas Muhammadiyah Yogyakarta (UMY), Indonesia

Achmad Muhammad, UIN Sunan Kalijaga Yogyakarta, Indonesia

Hendro Widodo, Universitas Ahmad Dahlan (UAD) Yogyakarta

Mundzirin Yusuf, UIN Sunan Kalijaga Yogyakarta, Indonesia

Sumedi, UIN Sunan Kalijaga Yogyakarta, Indonesia

Sukamto, Universitas Muhammadiyah Yogyakarta (UMY), Indonesia

Sumarsono, UIN Sunan Kalijaga Yogyakarta Indonesia

Sarjilah (Lembaga Penjaminan Mutu Pendidikan) Yogyakarta

Fathur Rahman, M.Si., Universitas Negeri Yogyakarta (UNY) Indonesia

\section{Editor Pelaksana}

Suryanto, Universitas Muhammadiyah Yogyakarta (UMY), Indonesia

Suyatno, Universitas Ahmad Dahlan (UAD) Yogyakarta

Farid Setiawan, Universitas Ahmad Dahlan (UAD) Yogyakarta

Alamat Redaksi:

Kantor Majelis Pendidikan Dasar dan Menengah Pimpinan

Wilayah Muhammadiyah D.I. Yogyakarta

J1. Gedongkuning No. 130B Yogyakarta

Kode Pos : 55171

Telephone : (0274) 377078

Facsimile : (0274) 371718

Website : www.dikdasmenpwmdiy.or.id

E-Mail : tajdidukasi@dikdasmenpwmdiy.or.id 


\title{
METODE SMALL GROUP DISCUSSION UNTUK MENINGKATKAN KOMPETENSI MEMBACA TEKS HORTATORY EXPOSITION
}

\author{
Utami Soifah \\ SMA Muhammadiyah 3 Yogyakarta \\ e-mail: tamisoifah75@gmail.com
}

\begin{abstract}
Abstrak
Tujuan dari penelitian ini adalah untuk mendeskripsikan penerapan metode pembelajaran Small Group Discussion (SGD) untuk meningkatkan kompetensi membaca. Subjek penelitian ini adalah siswa kelas XI IPA 3 SMA Muhammadiyah 3 Yogyakarta. Penelitian Tindakan Kelas ini dilaksanakan dalam dua siklus. Masing-masing siklus terdiri dari 4 tahap: perencanaan, tindakan, pengamatan dan refleksi. Metode pengumpulan data menggunakan tes dan observasi; tes untuk mengukur kemampuan siswa dalam membaca sedangkan lembar observasi bertujuan mengamati aktifitas guru dan siswa. Hasil penelitian menunjukkan bahwa penggunaan SGD dapat meningkatkan kompetensi membaca. Hal ini ditunjukkan dengan adanya peningkatan jumlah siswa yang mencapai nilai Kriteria Ketuntasan Minimal (KKM). Pada siklus I ada 55.6\% siswa yang tuntas dan pada siklus II meningkat menjadi 77.8\%. Kompetensi membaca siswa mengalami peningkatan ketika siswa saling bertukar pendapat dan informasi terhadap bacaan pada materi teks Hortatory Exposition. Penelitian ini juga menemukan ada keuntungan dan kelebihan dalam penerapan SGD.
\end{abstract}

Kata Kunci: Small Group Discussion; kompetensi membaca; teks Hortatory Exposition

\section{A. PENDAHULUAN}

Dalam pembelajaran bahasa Inggris di SMA, siswa diharapkan dapat menguasai empat ketrampilan bahasa (skill) yaitu mendengarkan (listening), berbicara (speaking), membaca (reading)dan menulis (writing). Dari keempat ketrampilan tersebut, salah satu ketrampilan yang harus dikuasai dalam pembelajaran adalah ketrampilan membaca. Kompetensi membaca adalah merupakan kemampuan berbahasa yang sangat penting. Menurut Tarigan
(2008: 7) membaca adalah suatu proses yang dilakukan serta dipergunakan oleh pembaca untuk memperoleh pesan yang hendak disampaikan oleh penulis melalui media kata-kata/ bahasa tulis. Sumber yang lain mengungkapkan bahwa membaca merupakan perbuatan yang dilakukan berdasarkan kerja sama beberapa keterampilan, yakni mengamati, memahami, dan memikirkan (Jazir Burhan dalam St.Y. Slamet, 2008:67). Secara singkat dapat dikatakan bahwa "reading" adalah "bringing meaning to 
and getting meaning from printed or written material", memetik serta memahami arti atau makna yang terkandung di dalam bahan tertulis (Finochiaro and Bonomo dalam H.G. Tarigan, 1986:8). Dari berbagai pengertian membaca di atas, dapat ditarik simpulan bahwa kegiatan membaca adalah memahami isi, ide atau gagasan baik yang tersurat maupun tersirat dalam bahan bacaan.

Banyak faktor yang diduga mempengaruhi kemampuan membaca. Faktor tersebut diantaranya situasi membaca, penguasaan kosakata dan tata bahasa, minat dan motivasi membaca, model atau metode pembelajaran yang diterapkan oleh pengajar. Metode pembelajaran dalam kegiatan belajar mengajar memberikan peran yang sangat penting. Menurut Siswanti (2012) ada beberapa penyebab kemampuan membaca siswa masih rendah. Faktor penyebab tersebut muncul dari baik siswa maupun guru. Pertama, faktor yang berasal dari siswa adalah (1) siswa tidak memiliki kosakata yang cukup, (2) siswa merasa takut, tidak semangat dalam dalam mengikuti kegiatan membaca, (3) Siswa tidak memiliki kesempatan untuk berdiskusi dengan temanapa yang sudah dibaca. Kedua, faktor yang mucul dari guru antara lain: (1) guru tidak mengimplementasikan teknik mengajar membaca yang melibatkan siswa untuk aktif, (2) guru mendiskusikan teks bacaan secara klasikal, (3) guru hanya meminta siswa untuk menterjemahkan teks bacaan.

Berdasarkan pengamatan guru sebelum pra penelitian, ditemukan permasalahan yaitu kemampuan membaca siswa masih rendah. Hal ini dapat dilihat ketika siswa diberi pertanyaan mengenai isi bacaan yang dibaca, mereka membutuhkan waktu yang lebih lama untuk menjawab dan melihat kembali bahan bacaan yang dibaca. Bahkan kadang-kadang masih tidak paham dengan kalimat jawaban yang ditulis. Sedangkan berdasarkan hasil tes penilaian Kompetensi Dasar (KD) yang dilaksanakan oleh guru, prosentase siswa yang belum tuntas masih dibawah kriteria ketuntasan minimal (KKM)

Rendahnya kemampuan membaca pada siswa di SMA Muhammadiyah 3 tersebut dikarenakan beberapa faktor baik dari guru maupun dari siswa. Faktor-faktor tersebut antara lain metode dari guru dimana masih sering menggunakan teacher centered learning. Dalam kegiatan membaca biasanya yang sering dilakukan oleh guru adalah memberikan siswa sebuah teks atau bahan bacaan, kemudian secara individu siswa menjawab pertanyaan dan kemudian membahas jawaban pertanyaan tersebut. Kegiatan tersebut dilakukan berulang, sehingga membuat siswa tidak semangat, jenuh dan bosan. Dari kondisi ini siswa menjadi kurang termotivasi untuk mengikuti pembelajaran. Sebagai hasilnya nilai tes siswa menjadi kurang memuaskan.

Berdasarkan permasalahan diatas, untuk meningkatkan kompetensi membaca teks Hortatory Exposition di SMA Muhammadiyah 3 Yogyakarta 
diterapkan metode Small group Discussion (SGD). SGD merupakan salah satu metode pembelajaran student centered. SGD adalah diskusi kelompok kecil untuk memecahkan masalah atau tugas yang diberikan. Dengan metode SGD ini siswa diharapkan lebih aktif dalam pembelajaran dan dapat menyelesaikan menyelesaikan masalah atau tugas yang diberikan dengan lebih baik. Hal ini sejalan dengan pembelajaran aktif. Pembelajaran aktif menurut Bonwell (1991) dalam Panduan Pengembangan Pembelajaran Aktif(Kemdikbud, 2017: 3) adalah merupakan pembelajaran yang melibarkan berpartisipasi siswa dalam proses pembelajaran, dimana siswa melakukan suatu kegiatan sesuai dengan tujuan pembelajaran dan tidak hanya pasif mendengarkan penjelasan guru. Dari penjelasan diatas, dapat disimpulkan bahwa Small Group Discussion merupakan bentuk pembelajaran aktif karena dalam diskusi siswa berpartisipasi aktif dalam pembelajaran.

Menurut Siti (2012) Pengertian Small Group Discussion secara sederhana menurut arti kata adalah sebagai berikut: small berarti kecil, Group berarti kelompok dan discussion berarti kegiatan membincangkan suatu masalah dan menyamakan persepsi antara dua orang atau lebih. Menurut Jadi dapat disimpulkan bahwa small group discussion adalah kegiatan bertukar pikiran di dalam kelompok kecil antara 4-5 orang.

Metode Small Group Discussion (SGD) adalah proses pembelajaran den- gan melakukan diskusi kelompok kecil tujuannya agar peserta didik memiliki ketrampilan memecahkan masalah terkait materi pokok dan persoalan yang dihadapi dalam kehidupan sehari-hari (Ismail, 2008).

Menurut Mulyasa (2010) dalam Ari Christiani (2014) metode Small Group Discussion ini merupakan cabang dari metode diskusi. Metode SGD lebih efektif diterapkan karena siswa dapat langsung berkomunikasi dengan anggota lain yang tidak terlalu banyak

Menurut Hasibuan dan Moedjiono (2000: 20) metode small group discussion juga berarti proses penglihatan dua atau lebih individu yang berinteraksi secara global dan saling berhadapan muka mengenai tujuan dan sasaran yang sudah ditentukan melalui tukar menukar informasi, mempertahankan pendapat atau pemecahan masalah.

Berdasarkan definisi diatas, dapat diambil kesimpulan bahwa Small Group Discussion merupakan metode dimana siswa dalam kelompok kecil berkomunikasi langsung dengan anggota lainnya dengan cara tukar menukar informasi, mempertahankan pendapat dengan tujuan untuk memecahkan masalah terkait materi pokok.

Penggunaan metode Small Group Discussion ini sejalan dengan beberapa hasil penelitian sebelumnya. Berdasarkan hasil penelitian sebelumnya yang dilakukan oleh Cecep ahmad S (2013) dengan judul "Keefektifan Metode Small Group Discussion di Dalam Pengajaran Membaca" menun- 
jukkan bahwa Metode Small Group Discussion efektif digunakan untuk pembelajaran Reading. Hal tersebut ditunjukan oleh rata-rata nilai siswa di kelas experimental $(=79.45, \mathrm{SE}=1.69$, $\mathrm{p}<0.05$ ) yang dengan signifikan lebih tinggi dari rata-rata nilai siswa di keLas control ( $\mathrm{M}=73.21, \mathrm{SE}=1.96)$. Selain itu, hasil penelitian juga menunjukan bahwa respon yang diberikan oleh siswa terhadap penggunaan Metode Small Group Discussion dalam pembelajaran reading sangat baik. Siwi Purwanti (2017) mengungkapkan bahwa metode Small Group Discussion dapat meningkatkan hasil belajar dan keaktifan mahasiswa PGSD UAD pada materi sains dasar. Wahyu Stiyoningsih (2016) dalam penelitiannya yang berjudul "Penerapan Metode Small Group Discussion sebagai Peningkatan Kemampuan berbicara Bahasa Arab (Studi Eksperimen Pembelajaran Kalam Kelas VIII di MTs Negeri gombong tahun Ajaran 2015/ 2016). Penelitian ini bertujuan untuk mengetahui apakah ada perbedaan antara kelompok eksperimen yang menggunakan metode Small Group Discussion dalam pembelajaran kalam dengan kelompok kontrol yang tidak menggunakan Small Group Discussion. Hasil penelitian tersebut menunjukkan adanya peningkatan yang lebih tinggi pada kelompok eksperimen dibanding kelompok kontrol. Kelompok eksperimen mendapatkan hasil post test sebesar 78, 2 sedangkan kelompok kontrol hanya mendapatkan hasil 69,5. Sehingga dapat disimpulkan bahwa metode Small Group Discussion dapat meningkatkan kemampuan berbicara bahasa arab.

Mengacu pada KTSP, pengajaran membaca di SMA kelas XI Semester Genap memiliki tujuan untuk mengembangkan kemampuan siswa dalam memahami dan menghasilkan teks fungsional pendek dan essay dalam bentuk teks Hortatory Exposition, Narrative dan Spoof. Siswa diharapkan juga dapat membaca teks dengan arti kata, frase, dan kalimat di dalamnya. Selain itu siswa diharapkan dapat merespon teks tertulis sederhana dengan akurat dan lancar.

Berdasarkan Modul Guru Pembelajar Bahasa Inggris Kelompok Kompetensi Profesional I, pengertian teks Hortatory Exposition adalah teks yang digunakan oleh penulis atau penutur untuk meyakinkan atau membujuk pembaca atau pendengar untuk melakukan sesuatu atau tidak melakukan sesuatu sesuai dengan saran atau rekomendasinya. Teks Hortatory exposition memiliki tujuan komunikatif yaitu mempengaruhi pembaca atau pendengar agar menyetujui dan atau menerima pendapat yang disajikan oleh penulis. Struktur teks hortatory exposition paling sedikit terdiri dari tiga paragraf yaitu :

a. Thesis. Thesis adalah pernyataan pendapat penulis akan suatu kasus..

b. Argument. Dalam argument ini penulis menyajikan alasan mengapa ada perhatian atau keprihatinan terhadap suatu isu atas sebuah fenomena..

c. Recommendation. Berisi tentang 
pernyataan tentang saran apa yang seharusnya atau tidak seharusnya sesuatu itu ada atau dilakukan.

Menurut Hakim (2014) dalam penelitiannya menyampaikan bahwa kemampuan membaca sangat komplek bukan hanya kemampuan tehnik membaca tapi kemampuan dalam pemahaman dan interpretasi isi bacaan. Dalam pembelajaran bahasa Inggris, salah satu tujuan membaca yang hendak dicapai adalah membaca pemahaman. Anderson (melalui Samsu Somadayo, 2011:12) menyatakan bahwa membaca pemahaman memiliki tujuan untuk memahami isi bacaan dalam teks. Tujuan tersebut antara lain: (1) untuk memperoleh rincian-rincian dan faktafakta, (2) mendapatkan ide pokok, (3) mendapatkan urutan organisasi teks, (4) mendapatkan kesimpulan, (5) mendapatkan klasifikasi, (6) membuat perbandingan atau pertentangan. Pembelajaran membaca bahasa Inggris diharapkan dapat mencapai tujuan-tujuan tersebut dengan melakukan aktifitas tertentu di dalam kelas.

Membaca pemahaman teks Hortatory exposition tentu saja membutuhkan metode yang tepat untuk mengajarkannya di kelas. Salah satu metode yang digunakan untuk menyampaikan materi teks Hortatory Exposition adalah dengan metode Small Group Discussion. Pengajaran membaca dengan metode Small Group Discussion disini dimaksudkan bahwa guru mendorong siswasiswa untuk bekerja dalam kelompok dimana siswa saling bertukar pikiran dan bekerja sama untuk memcapai tujuan kelompok atas pemahaman bacaan yang dibaca.

Metode ini diharapkan dapat membantu siswa dalam memahami berbagai jenis teks Hortatory Exposition. Hal ini dikarenakan siswa akan terlibat aktif, saling bertukar pendapat, dan berada dalam suasana yang lebih menyenangkan.

Berdasarkan pemaparan diatas, maka rumusan masalah dalam penelitian ini adalah Bagaimanakah metode pembelajaran Small Group Discussion (SGD) diterapkan untuk meningkatkan kompetensi membaca pada kelas XI IPA 3 di SMA Muhammadiyah 3 Yogyakarta? Tujuan penelitian ini untuk mengetahui bagaimana Mendiskripsikan penerapan metode pembelajaran Small Group Discussion (SGD) untuk meningkatkan kompetensi membaca pada kelas XI IPA 3 di SMA Muhammadiyah 3 Yogyakarta.

\section{B. METODE PENELITIAN}

Penelitian ini merupakan jenis penelitian tindakan kelas. Penelitian ini dilaksanakan dalam empat tahap yaitu perencanaan, pelaksanaan, pengamatan dan refleksi. langkah-langkah dalam penelitian tindakan kelas ini,menggunakan bentuk disain yang disusun oleh Kemmis dan Mc Taggart (Suharsimi Arikunto, 2010: 132). Adapun bentuk desain penelitian adalah sebagai berikut: 


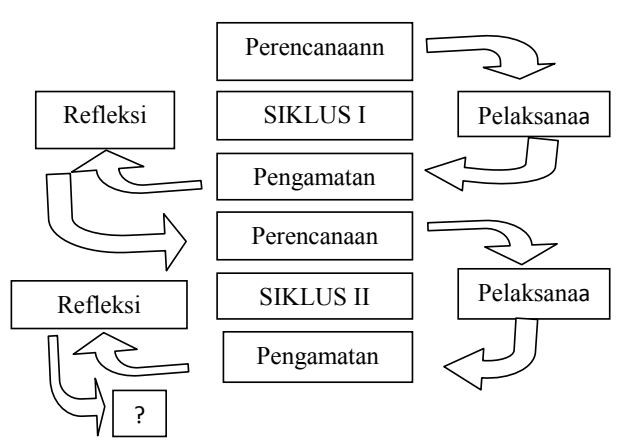

Gambar 1. Desain Penelitian Tindakan Kelas

Alur siklus tersebut menggambarkan proses pelaksanaan setiap siklusnya, dimana setiap siklus melalui empat tahap mulai dari perencanaan, dilanjutkan dengan pelaksanaan tindakan, pengamatan terhadap tindakan dan diakhiri dengan refleksi. Kekurangan yang ditemukan pada siklus I akan diperbaiki pada siklus selanjutnya. Siklus selanjutnya merupakan kelanjutan dari siklus sebelumnya.

Menurut Mohamad Asrori (2007: 6), Penelitian Tindakan Kelas merupakan suatu bentuk penelitian yang bersifat reflektif dengan melakukan tindakan-tindakan tertentu untuk memperbaiki dan meningkatkan praktik pembelajaran di kelas secara lebih berkualitas sehingga siswa dapat memperoleh hasil belajar yang lebih baik. Dengan penelitian ini diharapkan dapat meningkatkan proses pembelajaran sehingga hasil belajar juga meningkat.

Penelitian ini dilaksanakan pada semester genap tahun pelajaran 2017/ 2018 mulai dari Januari sampai Februari
2018. Subyek penelitian ini adalah siswa kelas XI IPA 3 SMA Muhammadiyah 3 Yogyakarta tahun pelajaran 2017/ 2018.

Instrumen yang digunakan dalam penelitian adalalah (1) tes. Menurut Suharsimi Arikunto (2010:193) tes adalah serentetan pertanyaan atau latihan atau alat lain yang digunakan untuk mengukur keterampilan, pengetahuan, inteligensi, kemampuan atau bakat yang dimiliki oleh individu atau kelompok. Pada penelitian ini tes yang dilakukan adalah tes kemampuan membaca teks Hortatory Exposition. Tes dilakukan pada akhir siklus yang digunakan untuk menunjukkan kemampuan membaca yang dicapai pada setiap siklus. (2) Observasi. Menurut Nana Sudjana (2005:66) observasi atau pengamatan adalah proses pengambilan data dalam penelitian dimana peneliti dan pengamat melihat situasi penelitian. (3) Catatan Lapangan. Catatan lapangan dalam penelitian ini merupakan sumber informasi yang sangat penting. Pembuatan catatan lapangan berdasarkan hasil observasi pembelajaran di kelas, suasana kelas, pengelolaan kelas, hubungan interaksi guru dan peserta didik, dan interaksi peserta didik dan peserta didik. Dalam penelitian ini dilakukan analisis data kualitatif dan data kuantitatif. Data kualitatif diperoleh dari hasil wawancara, observasi dan catatan lapangan. Wawancara dilakukan dengan siswa selama penelitian untuk mengetahui pendapat, kekurangan dan kelebihan dari tindakan yang dilakukan. Observasi 
dengan menggunakan catatan lapangan dalam setiap siklus yang dilakukan oleh peneliti dan pengamat. Setelah data terkumpul, peneliti dan pengamat melakukan diskusi untuk merefleksikan temuan-temuan selama proses pembelajaran di kelas. Untuk data kuantitatif diperoleh dari tes kemampuan membaca siswa. Untuk mengolah data kuantitatif, statistik sederhana digunakan untuk penyekoran hasil tes. Tes yang dilakukan adalah untuk mengetahui kemampuan membaca siswa. Skor yang diperoleh diubah kedalam skala angka (0-100) dengan rumus sebagai berikut.

$$
\text { Nilai }=\frac{\sum \text { Perolehan Skor }}{\sum \text { Skor Maksimal }} \times 100
$$

Penelitian ini dikatakan berhasil dan ada peningkatan, ditandai dengan ketercapaian nilai siswa diatas Kriteria Ketuntasan Minimal (KKM) mencapai minimal $75 \%$. Jadi jika jumlah siswa yang mencapai KKM dalam satu kelas melampaui $75 \%$ maka siklus dalam penelitian ini dihentikan. Adapun KKM dalam penelitian ini adalah 77 .

\section{HASIL DAN PEMBAHASAN}

\section{Kondisi Awal}

Sebelum melakukan penelitian, dilakukan observasi pada proses pembelajaran dan penggunaan metode pembelajaran di kelas. Menurut hasil pengamatan, pendekatan pembelajaran membaca yang sering digunakan adalah teacher centered (berpusat pada guru). Siswa membaca teks secara individu, menjawab pertanyaan dan kemudian dibahas. Sehingga dalam aktivitas di kelas, siswa jarang berinteraksi dengan teman dan sering ditemukan siswa yang tidak termotivasi untuk memahami materi.

Hasil penilaian KD sebelumnya juga menunjukkan hasil yang kurang memuaskan. Nilai rata-rata yang diperoleh adalah 63 dan hanya 15 siswa yang mencapai nilai ketuntasan minimal.

\section{Deskripsi Siklus I}

a. Perencanaan

Pada tahap perencanaan ini ada beberapa tahap yang perlu dilakukan peneliti yaitu menyusun Rencana Pelaksanaan Pembelajaran (RPP) dengan materi teks Hortatory Exposition dengan metode Small Group Dicussion. RPP ini berperan sebagai pedoman dalam melaksanakan kegiatan pembelajaran. Perencanaan selanjutnya adalah menyusun Lembar Kerja Siswa (LKS), menyusun lembar observasi guru dan lembar observasi siswa dan menyusun soal evaluasi yang akan digunakan pada akhir siklus I.

b. Pelaksanaan

Untuk Pertemuan Pertama siklus I dilaksanakan pada hari Rabu, 24 Januari 2018 jam ke 3, 4 (08.40-10.00). Pada tahap tindakan ini, peneliti memulai kegiatan pembelajaran dengan salam pembuka, mengajak siswa untuk doa bersama dan mengecek presensi. Kemudian guru melakukan apersepsi untuk memberikan motivasi dan mengarahkan siswa untuk masuk pada topik teks yang dibahas.Dilanjutkan dengan menjelas- 
kan tujuan yang akan dicapai. Guru juga menayangkan beberapa gambar berhubungan dengan topik yang dibahas yaitu tentang wearing helmet.

Setelah kegiatan awal selesai, guru melanjutkan dengan kegiatan inti dimana siswa melakukan proses pembelajaran dengan menerapkan Small Group Discussion dengan beberapa langkah. Langkah pertama diawali dengan guru membagi siswa dalam kelompok kecil dengan jumlah 4 siswa per kelompok. Pembagian kelompok dilakukan dengan cara random, yaitu siswa menghitung angka satu sampai sembilan sesuai dengan jumlah kelompok. Langkah selanjutnya guru membagikan lembar kerja siswa sesuai dengan materi yang dibahas dan siswa menyelesaikan tugas yang diberikan dengan didampingi oleh guru. Tugas yang harus diselesaikan adalah menjawab pertanyaan berdasarkan teks yang dibaca.

Setelah menyelesaikan tugasnya, siswa mempresentasikan hasil diskusi kelompok dan siswa dari kelompok lain memberikan tanggapan atau pertanyaan berhubungan dengan teks yang dibahas. Namun tidak semua kelompok dapat mempresentasikan hasilnya dikarenakan keterbatasan waktu. Hanya ada dua siswa yang memberikan pertanyaan kepada kelompok lain. Setelah kegiatan presentasi berakhir, guru memberikan konfirmasi dan pembahasan terhadap jawaban yang didiskusikan siswa.

Kegiatan pembelajaran memasuki kegiatan akhir dimana guru membimbing siswa untuk membuat kesimpulan bersama-sama, kemudian guru memberikan umpan balik terhadap proses ataupun hasil pembelajaran pada pertemuan. Sebelum pelajaran berakhir, guru meminta siswa mengumpulkan hasil diskusi dan kemudian pembelajaran diakhiri dengan salam penutup.

Setelah pertemuan pertama, guru melanjutkan pertemuan kedua yang dilaksanakan pada hari Sabtu, 27 Januari 2018 pada jam ke 4,5 (09.20-11.05 dengan terpotong waktu istirahat). Untuk pertemuan kedua, guru melakukan kegiatan pembelajaran yang hampir sama dengan pertemuan pertama.

Kegiatan diawali dengan guru memberi salam pembuka, mengajak siswa untuk doa bersama dan mengecek kehadiran siswa. Kemudian guru melakukan tanya jawab tentang materi pada pertemuan sebelumnya. Agar siswa lebih termotivasi, guru selanjutnya menjelaskan tujuan yang akan dicapai. Dilanjutkan guru menayangkan sebuah video yang membantu siswa memahami topik yang dibahas yaitu tentang Consuming water to be beautiful.

Kegiatan selanjutnya memasuki kegiatan inti. Kegiatan dimulai dengan membagi siswa dalam kelompok kecil dengan jumlah 4 siswa per kelompok. Pembagian kelompok yang dilakukan masih dengan cara random. Selanjutnya guru membagikan lembar kerja siswa. Adapun tugas yang dibahas dalam kelompok adalah mengurutkan kalimat yang disediakan menjadi teks Hortatory Exposition yang padu dan didalam kelompok siswa kemudian membuat per- 
tanyaan tentang teks yang dibaca. Siswa menyelesaikan tugas yang diberikan dengan didampingi oleh guru. Beberapa kelompok dapat menyelesaikan dengan cepat, namun beberapa kelompok membutuhkan waktu yang lebih lama.

Kegiatan selanjutnya adalah siswa mempresentasikan hasil diskusi kelompok dan siswa dari kelompok lain memberikan tanggapan atau pertanyaan berhubungan dengan teks yang dibahas. Namun hanya ada beberapa siswa yang memberikan pertanyaan. Setelah presentasi berakhir guru memberikan konfirmasi dengan hasil diskusi.

Untuk kegiatan akhir, guru membimbing siswa untuk menyimpulkan pelajaran bersama-sama, kemudian guru memberikan masukan terhadap proses ataupun hasil pembelajaran. Guru juga memberikan pekerjaan rumah sebagai tindak lanjut dan diakhiri dengan berdoa bersama.

Diakhir pertemuan kedua, guru memberikan tes untuk evaluasi kemampuan membaca. Berdasarkan hasil tes penelitian pada siklus I, data yang diperoleh adalah sebagai berikut:

Tabel 1. Data Kemampuan Membaca Siswa pada Siklus I

\begin{tabular}{|c|l|c|}
\hline No & \multicolumn{1}{|c|}{ Point } & Siklus I \\
\hline 1. & Nilai Tertinggi & 95 \\
\hline 2. & Nilai Terendah & 45 \\
\hline 3. & Nilai Rata-rata & 76.81 \\
\hline 4. & Banyaknya siswa yang tuntas & 20 \\
\hline 5. & $\begin{array}{l}\text { Banyaknya siswa yang belum } \\
\text { tuntas }\end{array}$ & 16 \\
\hline
\end{tabular}

\begin{tabular}{|c|l|c|}
\hline No & \multicolumn{1}{|c|}{ Point } & Siklus I \\
\hline 6. & Persentase siswa yang tuntas & $55.6 \%$ \\
\hline 7. & $\begin{array}{l}\text { Persentase siswa yang belum } \\
\text { tuntas }\end{array}$ & $44.4 \%$ \\
\hline
\end{tabular}

Menurut data diatas rata-rata nilai pada siklus I yaitu 76.81 dengan nilai tertinggi yaitu 95 dan nilai terendah yaitu 45. Hal ini menunjukkan bahwa 20 siswa atau 55.6\% siswa memperoleh ketuntasan dan 16 siswa atau 44.4\% siswa belum tuntas. Ketuntasan kemampuan membaca siswa pada siklus I belum mencapai target yang dicantumkan pada indikator keberhasilan yaitu 75\% dari ketuntasan belajar, sehingga penelitian dilanjutkan ke siklus II.

\section{c. Pengamatan}

Kegiatan observasi ini dilakukan oleh peneliti dan kolaborator pada saat pelaksanaan proses pembelajaran dikelas. Dari hasil pengamatan tersebut, maka ditemukan beberapa hal yang terjadi di kelas. Penggunaan waktu dikelas masih belum efektif. Hal ini terlihat ketika pembagian kelompok. Begitu pula ketika siswa berdiskusi, ada siswa yang justru malah mengobrol, tidak langsung menyelesaikan tugas.

Dalam hal pembagian kelompok, siswa dengan kemampuan lebih tidak tersebar secara merata di kelompokkelompok. Hal ini mengakibatkan beberapa kelompok belum menyelesaikan tugas pada waktu yang ditentukan.

Pemilihan materi juga berpengaruh pada waktu yang dibutuhkan untuk menyelesaikan tugas. Pada pertemuan 
pertama, materi dirasa cukup sulit bagi siswa sehingga siswa membutuhkan waktu yang lebih lama untuk memahami.

Pada saat siswa mulai bekerja di dalam kelompok, masih ditemukan siswa yang tidak bekerja secara serius dalam kelompok. Hal ini disebabkan mereka hanya mengandalkan teman dalam menyelesaikan tugas dalam kelompoknya.

Kolaborator dan peneliti menemukan bahwa pada waktu presentasi berlangsung, tidak semua siswa memperhatikan presentasi dari kelompok lain. Hal ini nampak dari beberapa siswa masih berbincang dengan kelompoknya sendiri. Begitu juga ketika memberi tanggapan atau pertanyaan presentasi dari kelompok lain, siswa masih belum termotivasi untuk menanggapi. Pada pertemuan pertama tercatat hanya 2 siswa yang bertanya dan 3 siswa pada pertemuan yang kedua.

d. Refleksi

Berdasarkan hasil pengamatan pada siklus I, maka peneliti dan kolaborator melakukan refleksi pada hari Selasa tanggal 30 Januari 2018. Hasil refleksi mengacu pada hasil pengamatan selama siklus I. Hasil refleksi diharapkan untuk meningkatkan proses pembelajaran selanjutnya. Agar penggunaan waktu lebih efektif, guru harus lebih memahami langkah-langkah dalam menerapkan Small Group Discussion.

Pembagian kelompok dilakukan dengan membagi expert (siswa yang memiliki kemampuan lebih dalam pe- lajaran) ke semua kelompok. Sehingga siswa yang pandai lebih tersebar dan bisa membantu dalam diskusi kelompok.

Pada tahapan diskusi, setiap siswa diberikan lembar kerja yang harus diselesaikan masing-masing sehingga dapat mengurangi ketergantungan pada teman yang lain.

Selama kegiatan presentasi berlangsung, setiap kelompok mendapatkan tugas untuk menanggapi hasil dari kelompok lainnya. Sekaligus menugaskan setiap siswa dalam kelompok untuk bertanya dan memberi reward nilai tambahan bagi siswa yang bertanya. Hal ini bertujuan untuk lebih memotivasi siswa dalam memberi tanggapan pada presentasi dari kelompok lain.

Untuk memperbaiki proses pembelajaran selanjutnya, peneliti melakukan penjaringan opini melalui wawancara dengan siswa. Dari hasil wawancara diperoleh data bahwa siswa merasa senang dengan penggunaan small group discussion. Metode ini dirasa lebih baik daripada metode sebelumnya. Siswa mengakui pemahaman tentang materi meningkat. Namun siswa memberikan saran diantaranya guru lebih mengontrol karena masih ada siswa yang tidak bekerja pada diskusi kelompok dan pembagian kelompok sebaiknya dibuat lebih merata.

\section{Deskripsi Siklus II}

a. Perencanaan

Memasuki siklus II, perencanaan yang dilakukan dengan menyusun 
Rencana Pelaksanaan Pembelajaran (RPP) dengan materi teks Hortatory Exposition untuk pertemuan pertama dan pertemuan kedua. Dilanjutkan dengan menyusun lembar kerja siswa untuk siklus II dan menyiapkan lembar observasi untuk guru dan lembar observasi siswa. Lembar observasi ini untuk mengetahui penerapan metode Small Group Discussion oleh guru dan aktifitas siswa selama proses pembelajaran berlangsung.

Berdasarkan hasil refleksi pada siklus I, peneliti beberapa nama siswa yang memiliki kemampuan lebih dalam pelajaran sesuai dengan jumlah kelompok. Untuk media pembelajaran, guru menyiapkan berupa kertas tebal berwarna dan spidol untuk setiap kelompok. Selain itu peneliti juga menyiapkan soal evaluasi yang akan digunakan pada akhir siklus II.

\section{b. Pelaksanaan}

Untuk tindakan siklus II, Pertemuan pertama dilaksanakan pada hari Rabu tanggal 31 Januari 2018. Pembelajaran pertama pada siklus II ini diawali dengan guru mmberi salam pembuka, berdoa bersama dan mengecek presensi. Kemudian guru melakukan apersepsi untuk memberikan motivasi dan mengarahkan peserta didik untuk masuk pada topik teks yang dibahas. Guru juga menyampaikan strategi pembelajaran yang digunakan dan tujuan pembelajaran yang akan dicapai. Untuk mengaitkan dengan pengetahuan siswa, guru menayangkan beberapa gambar terkait dengan topik yang dibahas yaitu the importance of breakfast.

Untuk kegiatan inti, guru melakukan langkah-langkah dalam penerapan SGD. Langkah pertama diawali dengan menunjuk 9 anak yang memiliki kemampuan lebih sebagai expert pada masing-masing kelompok. 9 anak tersebut ditunjuk juga sebagai ketua kelompok. Kemudian siswa yang lain dibagi menjadi kelompok kecil sesuai dengan ketua kelompok yang ada.

Selanjutnya, guru membagikan lembar kerja siswa berserta media yang digunakan yaitu kertas warna tebal dan spidol. Siswa diminta untuk membuat chart struktur teks berdasarkan materi yang diberikan. Supaya pembelajaran berjalan dengan lebih efektif, guru memberikan instruksi tugas yang harus diselesaikan dan alokasi waktu yang digunakan. Selama siswa menyelesaikan tugas, guru mendampingi dalam mendiskusikan tugas dan kegiatan presentasi.

Pada kegiatan presentasi, setiap kelompok yang maju mendapatkan tanggapan atau pertanyaan dari kelompok lain. Pada kegiatan presentasi ini semakin banyak siswa yang memberikan tanggapan atau pendapat. Setelah presentasi berakhir, guru memberikan konfirmasi jawaban.

Untuk kegiatan terakhir, guru bersama-sama dengan siswa menyimpulkan materi. Guru juga menyampaikan refleksi untuk pembelajaran yang berlangsung. Pembelajaran diakhiri dengan doa bersama. 
Pertemuan kedua untuk siklus II dilaksanakan pada hari Rabu tanggal 7 Februari 2018. Untuk kegiatan awal, guru memulai pembelajaran dengan salam pembuka, doa bersama dan mengecek kehadiran siswa. Dilanjutkan dengan penyampaian tujuan pembelajaran dan strategi yang pergunakan pada pertemuan itu. Selanjutnya guru melakukan tanya jawab sebagai apersepsi untuk mengingat pelajaran pada pertemuan selanjutnya dan kemudian menayangkan beberapa gambar untuk masuk masuk dalam topik yang dibahas yaitu cheating.

Seperti pada pertemuan sebelumnya, di kegiatan inti, guru melakukan langkah-langkah pembelajaran dengan menerapkan metode SGD.kegiatan diawali dengan guru memanggil kedepan kelas beberapa siswa sebagai ketua kelompok. Siswa yang ditunjuk ini memiliki kemampuan lebih pada pelajaran. Dilanjutkan dengan membagi siswa menjadi kelompok kecil dengan anggota 4 siswa. Guru kemudian memberikan lembar kerja siswa. Pada pertemuan kedua ini siswa diminta menyusun argumen berdasarkan thesis. Siswa melakukan diskusi dan guru mendampingi siswa apabila menemukan kesulitan. Kegiatan selanjutnya adalah siswa mempresentasikan hasil diskusi mereka dan kelompok lainnya memberikan tanggapan dengan argumen yang disampaikan. Beberapa siswa sangat antusias memberikan tanggapan dan beberapa siswa juga mengajukan pertanyaan. Semua kelompok bisa mempresentasikan hasil diskusinya dan mendapatkan beberapa pertanggapan atau komentar. Sebagai penutup, guru memberikan konfirmasi dengan jawaban dari kelompok. Kegiatan pembelajaran diakhiri dengan menyimpulkan materi secara bersama-sama. Beberapa siswa dengan sukarela menyampaikan kesimpulannya. Guru juga memberikan refleksi terhadap pembelajaran yang berlangsung dan diakhiri dengan doa penutup.

Berdasarkan hasil kemampuan membaca siswa pada siklus II diperoleh data sebagai berikut:

Tabel 2. Data Kemampuan Membaca Siswa pada Siklus II

\begin{tabular}{|c|l|c|}
\hline No & \multicolumn{1}{|c|}{ Point } & Siklus I \\
\hline 1. & Nilai Tertinggi & 95 \\
\hline 2. & Nilai Terendah & 50 \\
\hline 3. & Nilai Rata-rata & 81.94 \\
\hline 4. & Banyaknya siswa yang tuntas & 28 \\
\hline 5. & $\begin{array}{l}\text { Banyaknya siswa yang belum } \\
\text { tuntas }\end{array}$ & 8 \\
\hline 6. & Persentase siswa yang tuntas & $77.8 \%$ \\
\hline 7. & $\begin{array}{l}\text { Persentase siswa yang belum } \\
\text { tuntas }\end{array}$ & $22.2 \%$ \\
\hline
\end{tabular}

Berdasarkan data diatas maka ratarata nilai pada siklus II yaitu 81.94. dengan nilai tertinggi yaitu 95 dan nilai terendah yaitu 50. Hal ini menunjukkan bahwa 28 siswa atau $77.8 \%$ siswa memperoleh ketuntasan dan 86 siswa atau $22.2 \%$ siswa belum tuntas. Ketuntasan kemampuan membaca siswa pada siklus II ini sudah mencapai target yang dican- 
tumkan pada indikator keberhasilan yaitu $75 \%$ dari ketuntasan belajar, sehingga penelitian diakhiri pada siklus II.

c. Pengamatan

Pada pelaksanaan tindakan siklus II, peneliti dan kolaborator melakukan pengamatan terhadap proses pembelajaran.Penggunaan waktu lebih efektif karena siswa dan juga guru sudah lebih memahami langkah kegiatan pembelajaran dengan SGD.

Pembentukan kelompok lebih cepat meskipun setiap pertemuan mereka selalu berganti ketua dan anggotanya. Pada saat penyelesaian tugas, kelompok juga bekerja lebih cepat karena ada siswa yang menjadi expert. Mereka bisa saling berbagi informasi sehingga keterlibatan siswa dalam diskusi juga lebih merata dibandingkan pada pertemuan sebelumnya.

Pada tahap presentasi, terlihat siswa lebih berani menyampaikan pertanyaan atau tanggapan terhadap kelompok yang presentasi karena setiap kelompok diberi tugas bertanya atau berkomentar apabila ada pendapat yang berbeda. Mereka juga terlihat antusias untuk bertanya karena adanya reward dari guru.

\section{d. Refleksi}

Berdasarkan hasil pengamatan pada pelaksanaan tindakan pada siklus II, secara keseluruhan kegiatan pembelajaran dapat berjalan dengan baik dan lebih lancar. Semangat dan keaktifan siswa lebih meningkat. Hal ini terlihat pada partisipasi siswa dalam diskusi kelompok lebih nampak. Kegiatan dis- kusi berjalan lebih efektif karena ada kerjasama dan saling membantu dalam menyelesaikan tugas. Siswa yang kurang paham bisa dibantu dengan siswa yang mempunyai kemampuan lebih. Dalam hal presentasi, kemampuan siswa untuk mempresentasikan hasil diskusi juga sudah lebih bagus dan keberanian bertanya atau menanggapi jawaban lebih meningkat.

Untuk mengetahui pendapat siswa, guru juga melakukan wawancara dengan beberapa siswa. Dari hasil wawancara siswa menyampaikan bahwa mereka senang dengan metode Small Group Discussion yang digunakan. Mereka bisa lebih rileks dalam belajar dan tidak malu jika ada yang bertanya dalam kelompok dan bisa saling bertukar informasi. Mereka juga lebih paham dengan materi karena setelah dibahas dalam kelompok, dipresentasikan terakhir mendapat masukan dari teman dan guru.

\section{Peningkatan Kompetensi Mem- baca Teks Hortatory Exposition setelah Penerapan Metode Small Group Discussion}

Dalam penelitian ini setiap siklus dilaksanakan dengan melalui tahapan perencanaan, tindakan, pengamatan dan refleksi. Siklus II merupakan kelanjutan dari siklus I. Data penelitian yang diperoleh adalah data tes yang berupa kemampuan membaca dan data non tes yang berupa observasi dan dokumentasi.

Setelah dilaksanakan penelitian mu- 
lai siklus I dan siklus II dengan metode Small Group Discussion untuk meningkatkan kemampuan membaca siswa kelas XI IPA 3 SMA Muhammadiyah 3 Yogyakarta dapat dijelaskan bahwa metode SGD dapat meningkatkan kemampuan membaca.

Hasil tes kemampuan membaca siswa kelas XI IPA 3 setelah dilaksanakan pembelajaran dengan metode SGD mengalami peningkatan. Hal ini dapat dibuktikan pada hasil penelitian yang menunjukkan nilai rata-rata dan ketuntasan belajar siswa XI IPA3. Nilai rata-rata kelas pada pembelajaran siklus 1 menunjukkan peningkatan bila dibandingkan pada tahap pratindakan yaitu dari 63.11 menjadi .76.81. Sementara persentase siswa yang telah mencapai KKM pada siklus I meningkat dari 50\% pada pratindakan menjadi $55.6 \%$ pada siklus I. Peningkatan ini dikarenakan siswa lebih mudah untuk memahami materi karena mereka lebih aktif dan ada saling berbagi informasi dalam kelompok.

Pada penelitian siklus I persentase keberhasilan belum mencapai $75 \%$ karena baru mencapai $55.6 \%$ dari siswa yang mencapai nilai diatas KKM. Untuk itu penelitian dilanjutkan pada siklus II dengan melihat catatan penting yang masih perlu diperbaiki pada pembelajaran berikutnya.

Tindakan pada siklus II masih menggunakan metode SGD namun lebih efektif dibanding siklus I. Hal ini dikarenakan penggunaan waktu lebih efektif, guru lebih intensif dalam men- dampingi kelompok dan siswa lebih aktif dan termotivasi dalam melaksanakan kegiatan diskusi.

Adanya upaya perbaikan pada siklus II, maka hasil pembelajaran mengalami peningkatan dibandingkan pada siklus I. Hal ini terlihat pada tabel berikut ini.

Tabel 3. Data perbandingan kemampuan membaca siswa pada siklus I dan siklus II

\begin{tabular}{|c|l|c|c|}
\hline No. & \multicolumn{1}{|c|}{ Point } & Siklus I & Siklus II \\
\hline 1. & Nilai Tertinggi & 95 & 95 \\
\hline 2. & Nilai Terendah & 45 & 50 \\
\hline 3. & Persentase Ketuntasan & $55.6 \%$ & $77.8 \%$ \\
\hline 4. & $\begin{array}{l}\text { Persentase Ketidaktun- } \\
\text { tasan }\end{array}$ & $44.4 \%$ & $22.2 \%$ \\
\hline
\end{tabular}

Untuk persentase ketuntasan hasil belajar jika disajikan dalam diagram, maka hasilnya adalah sebagai berikut:

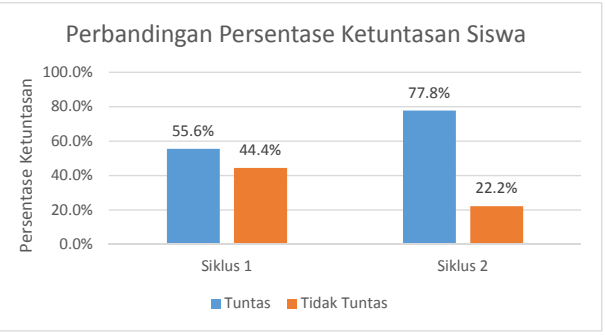

Gambar 2. Diagram perbandingan ketuntasan belajar pada siklus I dan siklus 2

Berdasarkan diagram diatas, persentase siswa yang telah mencapai KKM mengalami peningkatan. Pada siklus I ketuntasan belajar mencapai $55.6 \%$. setelah dilakukan penelitian siklus II, ketuntasan belajar mengala- 
mi peningkatan yaitu menjadi $77.8 \%$. dengan adanya persentase ketuntasan yang sudah mencapai kriteria yang ditetapkan peneliti yaitu $75 \%$, maka penelitian dihentikan pada siklus II.

Kenaikan prestasi belajar bisa jadi dikarenakan semangat dan motivasi siswa lebih meningkat. Siswa menjadi aktif dalam menelaah materi dan bekerja sama serta lebih bertanggung jawab dalam memahami materi dengan metode SGD.

Setelah melaksanakan penelitian dalam dua siklus ada beberapa keunggulan dan kelemahan dalam penerapan Small Group Discussion (SGD) di kelas XI IPA 3 SMA Muhammadiyah 3 Yogyakarta. Keunggulan tersebut antara lain (1) SGD dapat meningkatkan motivasi dalam pembelajaran membaca, (2) SGD dapat membuat siswa lebih aktif dalam proses pembelajaran, (3) SGD membuat suasana kelas menjadi lebih nyaman dan lebih rileks bagi anakanak untuk belajar, (4) SGD membuat siswa dapat saling sharing dan bertukar informasi dalam menyelesaikan tugas. Adapun kelemahan SGD anatar lain (1) situasi kelas menjadi lebih ramai terutama ketika pembentukan kelompok, (2) tidak semua kegiatan siswa selama SGD terkontrol oleh guru, (3) siswa lebih banyak menggunakan bahasa ibu/ bahasa Indonesia.

\section{KESIMPULAN}

Berdasarkan hasil penelitian dan pembahasan yang telah diuraikan se- belumnya dapat disimpulkan sebagai berikut:

1. Pembelajaran dengan menggunakan metode Small Group discussion dapat meningkatkan kompetensi membaca teks Hortatory Exposition siswa. Peningkatan ini terlihat pada peningkatan jumlah siswa yang mencapai ketuntasan belajar pada setiap siklus. Jumlah siswa yang memperoleh ketuntasan belajar juga meningkat. Pada siklus I jumlah siswa yang tuntas adalah 20 siswa dengan persentase $55.6 \%$ sedangkan jumlah siswa yang belum tuntas sebanyak 16 siswa dengan persentase $44.4 \%$. Pada siklus II siswa yang tuntas meningkat menjadi 28 siswa dengan persentase $77.8 \%$ dan siswa yang belum tuntas adalah 8 siswa dengan persentase $22.2 \%$.

2. Metode Small Group Discussion (SGD) dapat dipergunakan untuk meningkatkan kompetensi membaca siswa. Dengan implementasi SGD ada perubahan situasi kelas, siswa lebih aktif dibandingkan kondisi sebelumnya. Siswa menjadi terlibat aktif dalam proses pembelajaran. Suasana kelas menjadi lebih dinamis pada waktu proses pembelajaran. Dengan membahas teks, mengerjakan tugas secara berkelompok, siswa lebih termotivasi dalam meningkat kemampuan membaca. Dengan berpartisipasi dalam kegiatan pembelajaran yang dilakukan peneliti, siswa lebih memahami ide utama, informasi detail, kosakata dan struktur teks. Ketertarikan dan partisipasi aktif siswa sangat mendorong untuk memahami materi 
sehingga pada akhirnya kemampuan siswa dalam membaca menjadi lebih baik.

\section{DAFTAR PUSTAKA}

Ahmad, Cecep. (2013). The Effectiveness of Small Group Discussion Technique in Teaching Reading. Skripsi Jurusan Pendidikan Bahasa Inggris, Universitas Pendidikan Indonesia

Asrori, Mohammad. 2007. Psikologi Pembelajaran. Bandung: CV Wacana Prima

Christiani, Ari. 2014. "Penerapan metode Small Group Discussion dengan Model Cooperative Learning untuk meningkatkan Hasil Belajar siswa di Sekolah Dasar". Jurnal PGSD. Vol.02 No.02 Tahun 2014

Hakim, Abdullah (2014). Peningkatan Kemampuan Membaca Pemahaman Melalui Metode CIRC bagi Siswa Kelas V SD Negeri Temanggal, Kalasan tahun Pelajaran 2013/ 2014. Skripsi Jurusan Pendidikan Pra Sekolah dan Sekolah Dasar. Universitas Negeri Yogyakarta

Hasibuan dan Moedjiono. (2000). Proses Belajar Mengajar. Bandung: Remaja Rosdakarya

Isfirochah, Siti (2012). Peningkatan Prestasi Belajar Siswa Melalui pembelajaran Small Group Discussion Pokok Bahasan Kisah sahabat Rosul pada Siswa Kelas V di SDn Soroyudan Kecamatan Mertoyudan
Kab. Magelang Tahun pelajaran 2011/ 2012. Skripsi Jurusan Tarbiyah. Sekolah Tinggi Agama Islam Negeri Salatiga

Ismail SM. (2008). Strategi Pembelajaran Agama Islam berbasis PAIKEM. Semarang: RaSail Media Group.

Kemdikbud RI. (2017). Panduan Pengembangan Pembelajaran Aktif. Jakarta: Direktorat Pembinaan SMA.

Kementerian Pendidikan dan Pebudayaan.(2013). Pedoman Pelatihan Implementasi Kurikulum 2013. Jakarta: BPSDMPK-PMP

Sudjana, Nana. (2005) Penilaian Hasil Proses Belajar. Bandung: Rosdakarya.

Pardjono,dkk (2007). Panduan PENELITIAN TINDAKAN KELAS. Yogyakarta: Lembaga Penelitian UNY Purwanti, Siwi. 2007. "Metode Small Group Discussion dapat Meningkatkan Hasil Belajar dan Keaktifan Mahasiswa PGSD UAD pada Materi sains Dasar." Jurnal Dialektika Jurusan PGSD.Vol. 7 No.1 Maret 2017

Samsu Somadayo. (2011). Strategi dan Teknik Pembelajaran Membaca. Yogyakarta: Graha Ilmu.

Siswanti, Fibrina hanung (2012) The Use of Small Group Discussion to Improve reading Comprehension. Jurusan Pendidikan Bahasa Inggris. Universitas Sebelas Maret

St. Y. Slamet. (2008). Dasar-dasar keterampilan berbahasa indonesia. 
Surakarta: UNS Press

Suharsimi Arikunto. (2010). Penelitian Tindakan Kelas. Jakarta: Bumi Aksara

Tarigan, Henry Guntur.(1986). Membaca Sebagai Suatu Keterampilan Bahasa. Bandung: Percetakan Angkasa

Tarigan, Henry Guntur.(2008). Membaca Sebagai Suatu Keterampilan Bahasa. Bandung: Percetakan Angkasa

Taufik Nugroho,dkk. (2016). Modul Guru Pembelajar Mata Pelajaran Bahasa Inggris SMA/SMK Kelompok Kompetensi Profesional I. Jakarta: Dirjen GTK Kementerian Pendidikan dan Kebudayaan
Wahyu Stiyoningsih. (2016).Penerapan Metode Small Group Discussion (SGD) sebagai Peningkatan Kemampuan Berbicara Bahasa Arab Studi Eksperimen Pembelajaran Kalam Kelas VIII di MTs Negeri Gombong Tahun 2015/2016. Skripsi Jurusan Fakultas ilmu Tarbiyah dan Pendidikan, UIN Sunan Kalijaga 